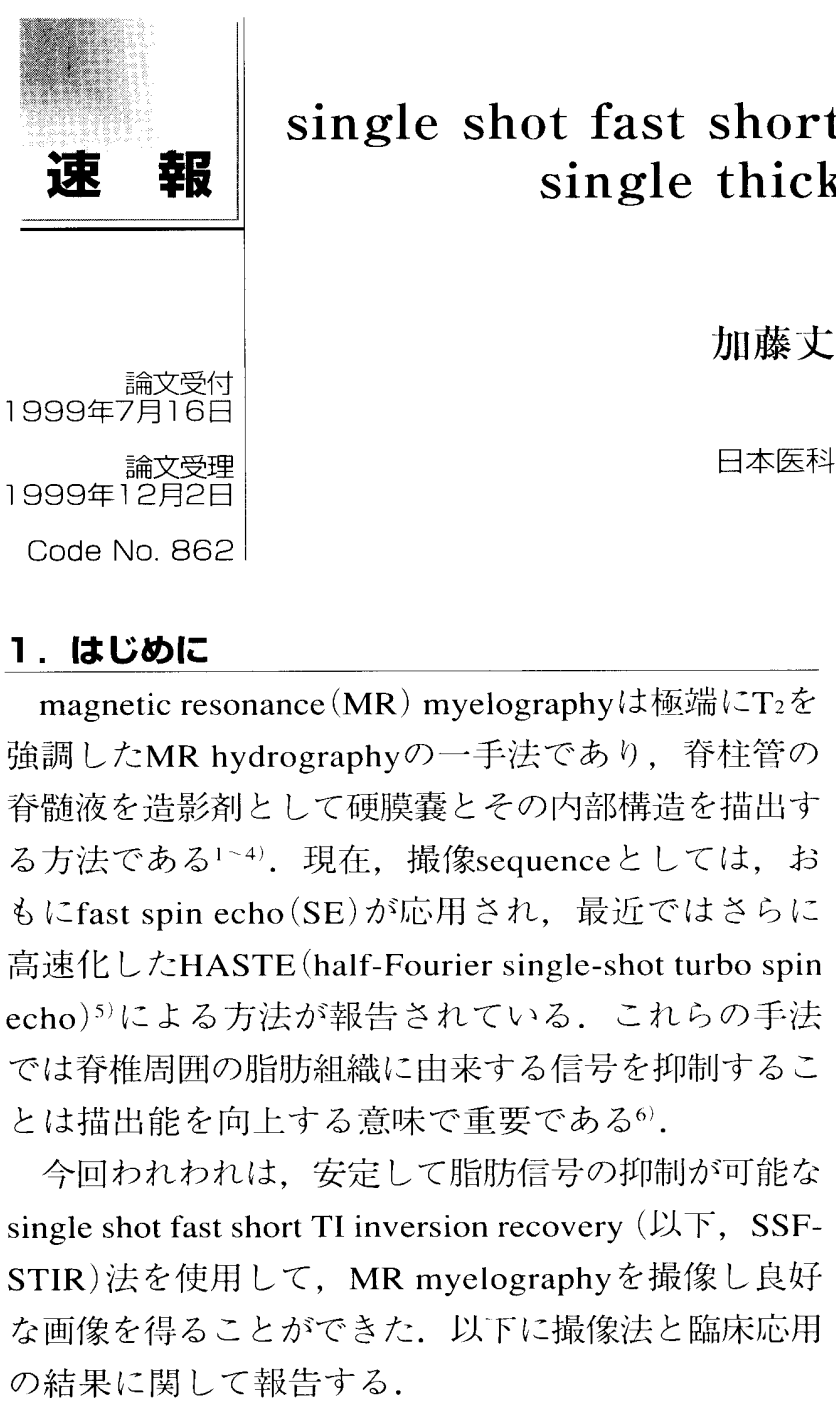

\section{2. 対象および方法}

対象はMR myelographyが施行された 5 症例であ る. 使用装置は, GE横河メディカルシステム株式会 社製 SIGNA Horizon 1.5 Teslaである。

SSF-STIR法 (TE $=197.7, T I=200 \mathrm{~ms}$, FOV 24 $30 \mathrm{~cm}$, matrix $512 \times 256$, 撮像加算数は 1 としhalf-
Fourier法を併用)にて撮像した. slice厚はそれぞれ症 例に合わせ $(30 \sim 50 \mathrm{~mm})$ に設定した. CTL-spine array coilを使用し撮像時間は2 3 秒であった、ヨード造影 郕によるmyelographyと比較検討した。

\section{3. 結 果}

SSF-STIR法によるMR myelographyは全症例で良好 な脂肪抑制画像が得られ、ヨード造影剂を用いた myelographyと同等に描出された。

Fig.1は56歳, 女性, 春䯣腫瘍の症例である。X線 myelographyでは完全ブロックを示しており, 腫瘍か ら頭側の春髄は描出されていない(Fig.1a).一力, MR myelographyでは脊柱管|内の腫瘍と病变の全体像 が明暸に描出された，脊随円錐部は䯑道外の腫瘍により 左側へ压排されている(Fig.1b). Gd-DTPA静注後のT2 強調矢状断像で腫瘍は明瞭な高信号病変として描出さ れている(Fig.1c)。Fig.2は40歳, 女性, 脊柱管狭窄症 の症例である． $\mathrm{T}_{2}$ 強調矢状断像に扔いて硬膜囊を前方 から压排するL4/5，L5/S椎問板が認められる (Fig.2a). MR myelographyでは, L4/5, L5/Sレベル に抢ける椎間板による圧排像が明瞭に描出され，X線 myelography所見と良好に一致した $(F i g .2 b ， c)$.

\title{
Single Thick Slice MR Myelography Using Single Shot Fast Short TI Inversion Recovery
}

JOJI KATO, TSUNEO WATANABE, and YOSHIHIKO KAWAMURA

Medical Imaging Center, Nippon Medical School Chiba Hokusou Hospital

Received July 16, 1999; Revision accepted Dec. 2, 1999; Code No. 862

Key words: MR imaging, MR myelography, Single shot fast short TI inversion recovery

別刷資料請求先：干270-1613 千葉県印旛郡印旛村鎌苮 1715

H本医科大学付属千枼北総病院 中央画像検査室 加藤丈司 宛 

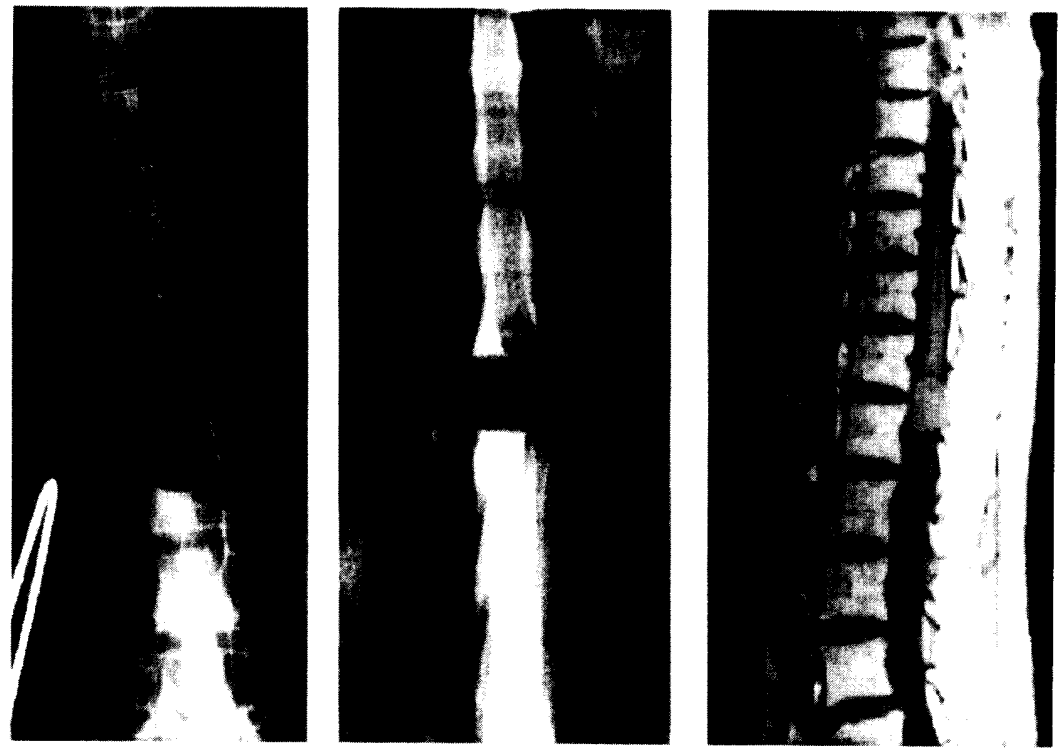

Fig. 1 A 56-year-old woman with tumor of the thoracic spine at Th 12 level.

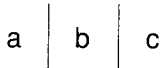

(a) X-ray myelography.

(b) MR myelography.

(c) Sagittal contrast enhanced SE MR image (TR/ $T E=500 / 16 \mathrm{~ms}$ ).

MR myelography shows compression of the spinal cord toward the left by the tumor.
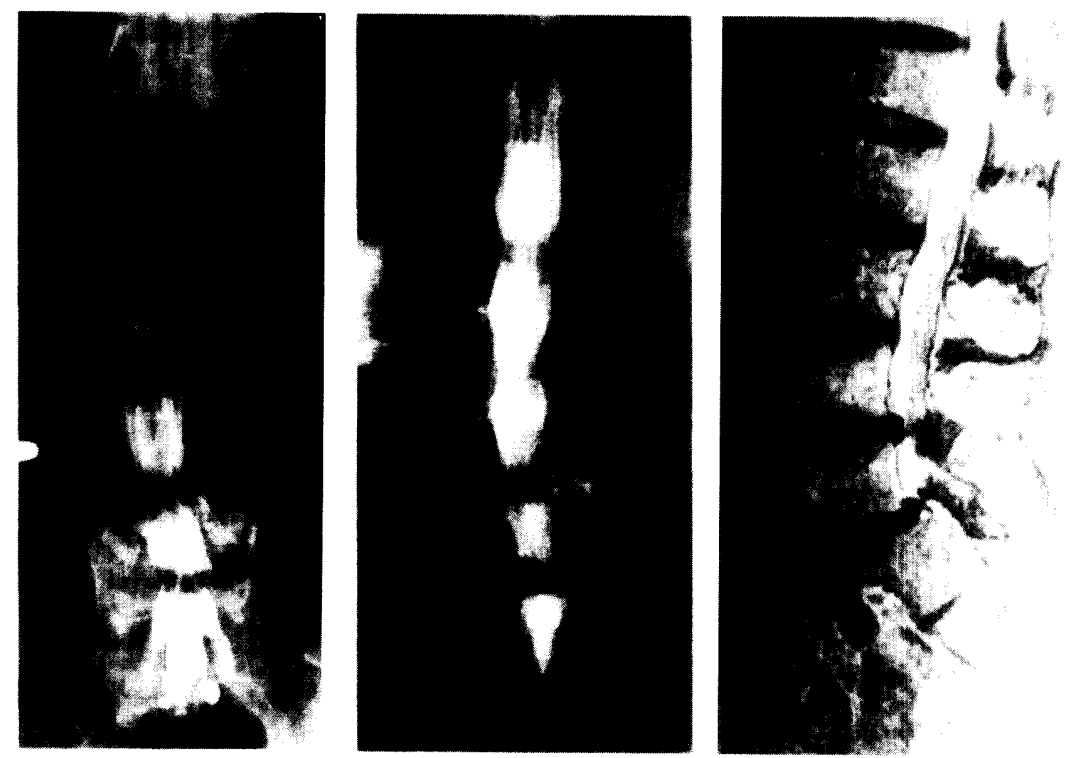

Fig. 2 A 40-year-old woman with spinal stenosis of the lumbar spine at L4/5 and L5/S level.

$a|b| c$

(a) X-ray myelography.

(b) MR myelography.

(c) Sagittal fast SE MR image (TR/TE $=4000 / 96 \mathrm{~ms}$ ).

In comparing MR myelography and conventional $x$ ray myelography, we obtained almost equal or better images with MR myelography.

\section{4. 考 察}

腰部脊髄造影は透視下にて腰椎穿刺を行い造影剂を 注入する力法であるが，腰椎穿刺が困難な症例もしば しばありその手技は煩雑で，なおかつ，患者の不安や 苦痛も大きい検査である。このため，より侵襲性の少
ない検査法が望まれていた。

一方，これに対しMR myelographyは放射線による被 暴, 腰椎穿刺や造影剂注入が必要のない非侵襲的検査 法といえる。しかし本法の問題点としては脊䯣液とと もに脊椎周囲の脂肪組織が高信号に描出されるため, 
病変部とのコントラストの低下や, artifactの増強を起 こしやすいことが挙げられる。この点,これまでは fast SEやHASTEに扢もにCHESS法 (chemical shift saturation) 7)併用する方法がとられていた。しかしこ のCHESS法は高い磁場の均一性が要求され，良好な抑 制効果が得られる撮像領域には限界も指摘されてい る。特に腰部のように長軸方向に広い撮像範囲を設定 する場合，撮像範囲の辺縁部で良好な抑制効果が得ら れないという問題がある.

これに対して，われわれが用いたSSF-STIRは SSFSEに前処理pulseとしてinversion pulseを付加した sequenceであり，原理的にはshort TI inversion recovery

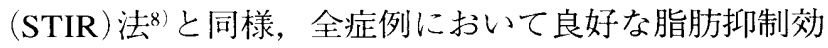
果を得ることができた。

今回検討したsingle thick slice法では 1 回の撮像で 1 枚の画像しか得られないため, 多方向からの観察を
必要とする場合では複数回の撮像が必要となる。しか しながら，1回の撮像に要する時間は約 2,3 秒と極め て短く, 方向を変えて撮像を繰り返しても，全体の検 査時間は短いため, 通常のMRIの検査の一部に容易に 追加することが可能と考えられる. 本法は脊髄液の内 部に脊髄や神経根が透過像として明瞭に描出され，そ の描出能も, 今回の検討では, conventional myelographyと良好な相関が得られ診断に有用な画像 が得られた。

\section{5. まとめ}

single shot fast short TI inversion recovery (SSF-STIR) 法を用いたMR myelographyを試みた。本法は良好な 脂肪抑制効果が得られ，かつ撮像時間も短く，有用な 手法になり得るものと考えられる。

\section{参考文献}

1) Henning $\mathbf{J}$, Friedburg $\mathbf{H}$, and Stroebel B: Rapid nontomographic approach to MR myelography without contrast agents. J Comput Assist Tomogr, 10, 375-378, (1986).

2) EL Gammal T, Brooks BS, Freedy RM, et al.: MR myelography: Imaging findings. AJR, 164, 173-177,(1995).

3) Eberhardt KEW, Hollenbach HP, Tomandl B, et al.: Threedimensional MR myelography of the lumbar spine: comparative case study to x-ray myelography. Eur Radiol, 7, 737-742, (1997).

4) VanDyke CW, Modic MT,Bcale SM, et al.: 3D MR myelography. J Comput Assist Tomogr, 16, 497-500, (1992).
5) Stark DD and Bradley WG Jr: Magnetic Resonace Imaging. Volume 1, 141, Mosby, St. Louis, (1999).

6) Krudy AG: MR myelography using heavily T2-weighted fast spin-echo pulse sequences with fat presaturation. AJR, 159, 1315-1320, (1992).

7) Frahm J, Haase A, Hanicke W, et al.: Chemical shift selective MR imaging using a whole-body magnet. Radiology, 156, 441-444, (1985).

8) Bydder GM and Young IR: MR imaging: Use of the inversion recovery sequence. J Comput Assist Tomogr, 9, 659-675, (1985).

Fig.156歳，女性，Th12レベルの脊髄腫瘍の症例。
(a) X線脊髄造影
(b) MR myelography
(c) $\mathrm{T}$ 強調矢状断像 $(\mathrm{TR} / \mathrm{TE}=500 / 16 \mathrm{~ms})$
MR myelographyでは, 腫瘍による脊髄の左方への圧排が認められる。

Fig.240歳，女性，L4-5およびL5-S の脊柱管狭窄症の症例
(a) X線脊髄造影
(b) MR myelography
(c) $\mathrm{T}_{2}$ 強調矢状断像 $(\mathrm{TR} / \mathrm{TE}=4000 / 96 \mathrm{~ms})$

X線脊髄造影とMR myelographyの比較では，拉㧍む权同等の画質を得ることができた。 